\title{
ACRL leads the way
}

\section{By Patricia Senn Breivik}

\section{ACRL's plan bas tangible results}

$\mathbf{A}$ s I mentioned in my vice-president's message in the 1994-95 ACRL Annual Report (CERL News, December 1995) I feel a great sense of urgency this year to expedite ACRL's progress in carrying out its new Strategic Plan. The plan, which is solidly based on ACRL membership's priorities, needs all of our attention, efforts, and resources to realize measurable outcomes.

\section{ACRL's four goals}

The plan's four goals are: 1) to provicle development opportunities for academic and research librarians and other library personnel that enhance their ability to deliver superior services and resources; 2 ) to collaborate with other professional organizations and associations of higher education in order to promote mutual interests; 3) to maintain at the national level a prominent role in planning and decision making for influencing information policy; and 4) to ensure that ACRL's operating environment provides efficiency in its use of resources and effectiveness in the delivery of services to its members and constituent units.

\section{Implementing the plan}

How will ACRL work towards these goals? How will we measure our progress? And how will we obtain the resources to carry out the goals? The Board spent a full day this fall working out a way to implement the Strategic Plan. Timelines and responsibilities for implementing the plan have been established. We have begun identifying criteria for assessing progress. The implementation plan is being shared with all ACRL units. Members may also write, call, or e-mail the ACRL office for copies. There are a number of activities that I am writing about that answer these questions.

\section{Progress to date}

ACRL is working to bring to your region its practical education programs that will help you do your job better. My President's Program will provide a multifaceted learning opportunity for conference participants and will also be packaged for use by chapters library staffs and other groups that wish to have it locally. ACRL vicepresident Bill Miller is already working with the ACRL Professional Education Committee to establish a mechanism to annually capture the best of ACRL programming at both the national and chapter levels for broader distribution.

ACRL is partnering with institutions and organizations in higher education to effect change in the whole teaching/learning process and has restructured its Professional Liaison Committee to become a new Council of Liaisons to improve its links to other associations. The Council is developing plans for a summit which ACRL. will host annually with other national organizations for the purpose of identifying key areas of mutual concern and for future collaboration,

In addition, the Membership Committee has been completely restructured and has a new focus. A number of other committees such as Research and Professional Education are redefining their roles in relation to the new Strategic Plan; discussion groups and section units are also engaged in this process.

ACRL has made a major contribution to ALA's Goal 2000 to support better representation of academic librarians' positions to Congress. CERL News will continue to offer monthly reports from Washington with the latest updates from Capital Hill and how it affects libraries.

The Board of Directors approved the establishment of the "ACRL Leadership Center," which will serve as a clearinghouse for information on leadership and centralize and coordinate activities and programs that focus on

(ACRL cont. on page 45)

Patricia Senn Breizik is ACRL president and dean of University Libraries at Wayne State University; e-mail. breivik@cms.cc.uayne.edu 


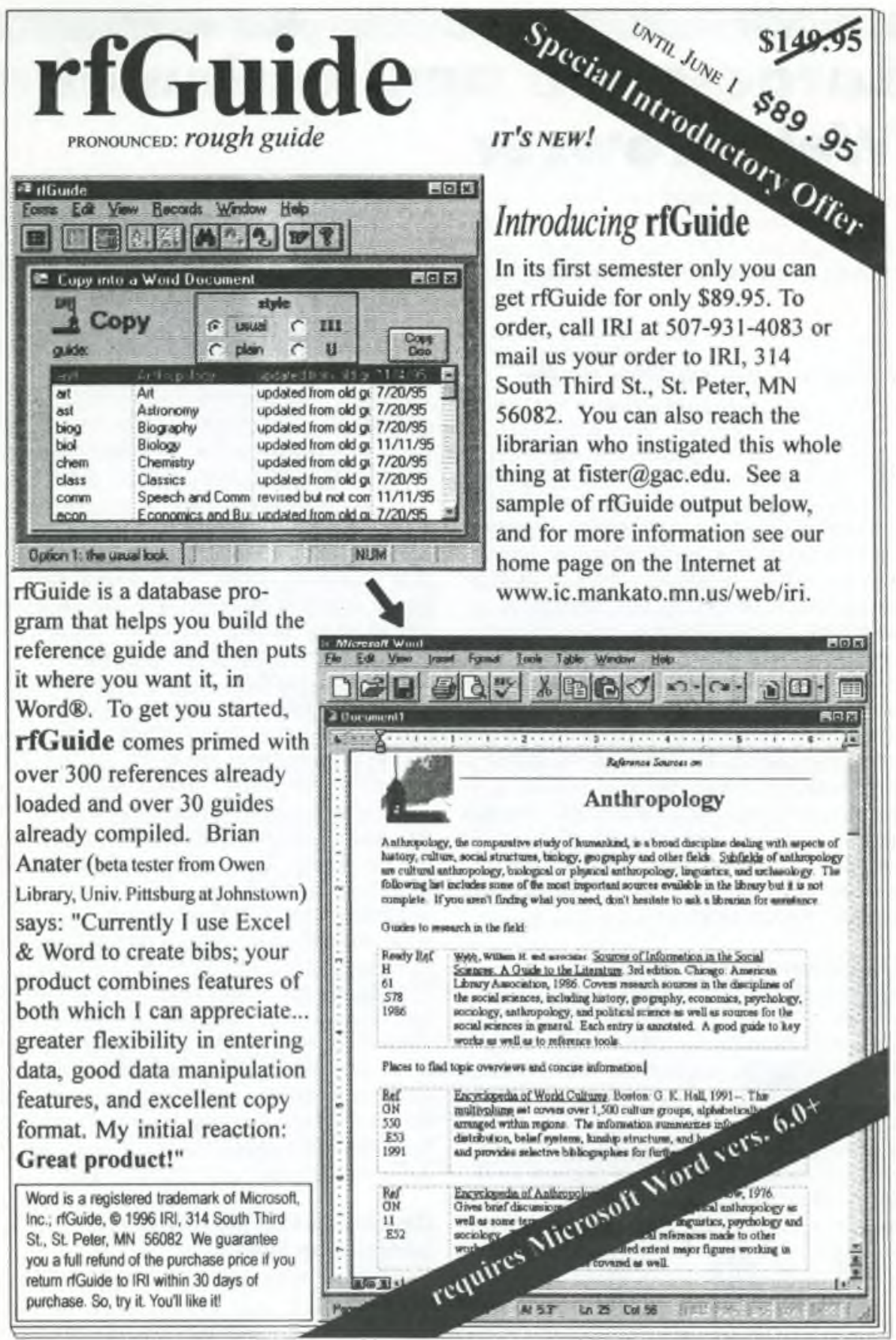


order catalogs, suppliers, and clubs (for those wild rubber stamp collectors), as well as a useful bibliography of books, videos, and magazines. $\$ 19.95$ (plus $\$ 4.00$ shipping). Cornuco pia Press, 4739 University Way N.E., Suite 1610-B, Seattle, WA 98105. ISBN 09641445-0-6.

\section{Temple of Liberty: Building the Capitol for a New Nation, by Pamela Scott (159 pages, July 1995), accompanied the Library of Congress exhibition in 1995 to commemorate the bicen-}

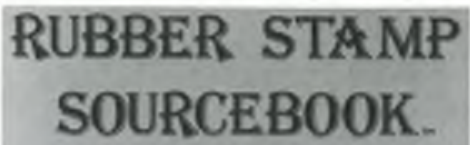

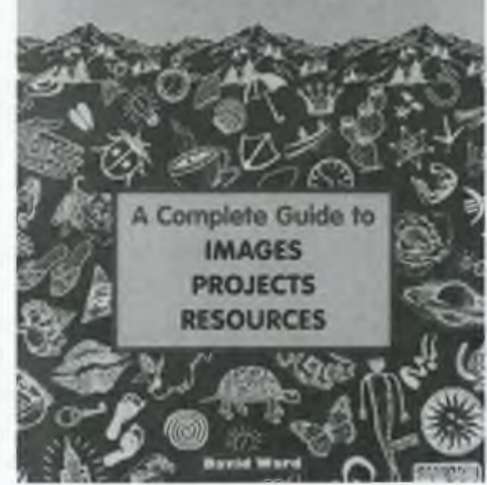

advice. $\$ 50.00$ (plus $\$ 6.00$ shipping). Infosources Pub., 140 Norma Rd., Teaneck, NJ 07666. ISBN 0-939486-34-2.

\section{Who's Who in Russia} and the CIS Republics, edited by Vladimir Morozov (328 pages, February 1995), presents biographies of more than 1,000 political leaders, military commanders, scientists, religious figures, entrepreneurs, and others from the former Soviet Union. An introduction explains the intricacies of the Commonwealth of Independent States, and appentennial of the U.S. Capitol building. Many rare drawings and prints held by $\mathrm{LC}$ were assembled for the occasion, along with documents and artifacts from other institutions that shed light on the design and construction of the Capitol. Scott, who served as guest curator for the collection, describes the symbology that went into the building, the design competition, and features of the dome, rotunda, porticoes, wings, and extension. A bibliography and photographic catalog of objects accompany the text. $\$ 21.95$. Oxford Univ. Press, 198 Madison Ave., New York, NY 10016. ISBN 0-19-509858-7.

\section{Washington Online: How to Access the Government's Electronic Bulletin Boards,} by Bruce Maxwell (340 pages, April 1995), offers detailed information on nearly 200 federal bulletin board systems (BBSs). Each listing provides voice and data telephone numbers, FedWorld gateway numbers, availability of a manual, time restrictions, background, and basic features and structure. Some of the more interesting places are: the Environmental Protection Agency's Online Library System, Telephone Time for Computers, and the Hay Locator Service. \$19.95. Congressional Quarterly Books, 1414 22nd St., N.W., Washington, DC 20037. ISBN 1-56802-000-7.

\section{A related reference is The Internet Guide} for the Legal Researcher, by Don MacLeod (306 pages, February 1995), which (after the obligatory Internet overview for newbies) lists and describes law-related listservs, talk and chat servers, gophers, online state resources, Web sites, and law libraries. Practical and succinct dices offer access by profession, government affiliation, honors or awards, and publications. $\$ 60.00$. Henry Holt and Co., 115 W. 18th St., New York, NY 10011. ISBN 0-8050-2691-6.

\section{(ACRL cont. from page 10)}

academic librarians as leaders. An advisory committee has already been appointed to develop the infrastructure for the center, and some exciting programs are in the developmental stages.

ACRL is engaged in a major cooperative project with the Middle States Association of Colleges and Schools, the Western Accrediting Commission for Senior Colleges and Universities, and the American Association of Higher Education to collect data for the purpose of documenting practices of schools in integrating information resources and technologies in higher education curricula across the United States. In addition to surveying the institutions in the six accrediting regions, a series of "best case" workshops was held and others are planned, a journal article is being written, and the American Council of Education is publishing the results of the study in book form.

\section{Share your ideas with us}

These are just the highlights of a number of tangible projects in the works at ACRL. Watch CERL News for updates on our progress and remember, the Strategic Plan is a living document. Be sure to send us your ideas and comments on how to make ACRL an effective organization that meets your needs. 